IJLLS

5,2

\section{GUEST EDITORIAL Case studies of lesson and learning study in initial teacher education programmes}

\author{
Penny Lamb \\ School of Education and Lifelong Learning, University of East Anglia, \\ Norwich, UK, and \\ Po Yuk Ko \\ Department of Curriculum and Instruction, \\ Hong Kong Institution of Education, Hong Kong, China
}

\begin{abstract}
Purpose - The integration of Lesson and Learning Study within initial teacher education programmes is still evolving and subject to many constraints (Parks, 2008). The purpose of this paper is to introduce the special issue which intends to stimulate and facilitate continued growth and interest in fostering models of Lesson and Learning Study within initial teacher education programmes.

Design/methodology/approach - The guest editors present each of the papers and introduce key themes and concepts.

Findings - The collection of papers shows the richness and value of embracing Lesson and Learning Study within initial teacher education programmes; whilst being mindful of the challenges and constraints inherent in the nature of national policy towards the training of teachers.

Originality/value - The collection of papers contribute to existing literature exploring the effectiveness and impact of Lesson and Learning Study within initial teacher education.
\end{abstract}

Keywords Collaborative inquiry, Preservice teachers, Lesson and Learning Study,

Reflection and reflexion

Paper type General review

\title{
Introduction
}

Lesson Study was originally developed in Japan to enhance the pedagogical competence of in-service teachers through working in collaboration in planning, implementing and assessing the research lesson. Due to its collaborative nature and evidence-based lesson analysis, Lesson and Learning Study have become an integral part in initial teaching training programmes (Cohan and Honigsfeld, 2006; Davies and Dunnill, 2008; Fernandez and Robinson, 2006; Ko, 2012; Marble, 2006, 2007; Parks, 2008, 2009; Sims and Walsh, 2009) in many places, providing preservice teachers a platform to experiment and improve their lesson design in authentic classroom settings. Indeed, "adaptions of 'formal' Lesson Study have been credited with having a positive impact on preservice teacher education" (Gurl, 2011, p. 523).

By conducting Lesson or Learning Study, preservice teachers learn to experience iterative cycles of collaborative planning, teaching in real classrooms, observing and evaluating their research lessons, revision and reflection. The collegial dialogues during discussions inculcate in student teachers an enquiry-based approach in solving learning problems with the major focus on improving learning and teaching. Such experimentation in professional problem-solving addresses not only the gap between theory and practice but also renders the student teachers an appropriate platform for 
"reflection-in-action" (Schon, 1987). The conscious review of the research lesson with the guidance from professional tutors or coaches of the initial teacher training programmes help prospective teachers achieve deep reflection and develop their pedagogical knowledge and instructional competence.

Case studies of lesson and learning study

The case studies in this issue: some similarities and differences

This special issue of the International Journal of Lesson and Learning Studies, "Case studies of Lesson and Learning Study in Initial Teacher Education programmes", introduces six articles submitted by teacher educators from around the world (Austria, England, Norway, Japan and Spain). Here, we share their research, practice and experiences of engaging in Lesson and Learning Study with preservice teachers and schools. This special issue, devoted to adapted models of Lesson and Learning Study, integrated within initial teacher education is timely when "opportunities for preservice teachers and experts to develop a shared language to describe innovative and effective teaching practices are lacking" (Santagata et al., 2007, p. 125). The collection of papers connects academics and practitioners involved in initial teacher education and shares how Lesson and Learning Study is contributing to preservice teachers' school-based experiences and exposure to the complexities of the classroom - as part of English Secondary (ages 11-18) postgraduate training provision (Cajkler and Wood, 2106; Lamb and Aldous, 2016); within an English as a Foreign Language context in Austria (Gierlinger et al. 2016); as a case study of mentoring roles and curriculum study in Japan (Chichibu, 2016); as part of a four-year pre-school preservice programme in Spain (Soto Gómez et al., 2016) and a cross-disciplinary approach in a four-year integrated initial teacher education programme in Norway for grades 1-7 and grades 5-10 (Munthe et al., 2016).

The presented articles all differ in the way in which their programmes organise school-based teaching opportunities for their preservice teachers. However, they are founded on the same premise, to provide beginning teachers with exposure to concrete examples of teaching in order to inform their own learning; and to provide the space to apply theory in practice (Santagata et al., 2007). Crucial to initial teacher education provision, these contextual school experiences "are often considered the primary place in which preservice teachers, by observing more experienced teachers, learn to teach" (Santagata et al., 2007, p. 124). Whilst the models and patterns of school practice vary from programme to programme, a common theme during these experiences concerns the relationships between the preservice teachers, school-based mentors and university teacher educators. Building on Elliott's (2012) comparison of the "laboratory" with the "apprenticeship" and "rationalist" models of learning to teach, this special issue presents a range of novel approaches towards incorporating Lesson and Learning Study into the school-based phases of training. What appears most illuminating from these small scale studies is their apparent scope for paving of the way towards the development of a science of teaching (Elliott, 2012). Similarities between the case studies also echo outcomes by which patterns of professional socialisation may begin to bear greater influence over organisation socialisation (Van Maanen and Schein, 1979) for preservice teachers as they embark on their early careers.

Summary comments on articles in this issue

Lamb and Aldous explore the role of Lesson Study in developing reflexivity by preservice teachers of Physical Education. They discuss how applying the principles of Strong Structuration Theory may inform understanding of how preservice teachers' 
IJLLS

5,2

80

active agency towards reflective practices are developed through engaging their internal structures (dispositions) with the external structures of initial teacher education. The conceptual paper explores how, through both Lesson Study and peer review, preservice teachers are empowered to draw upon each other as reflective practitioners who strategically engage with the demands of the external structures, developing practices beyond traditional support mechanisms of their training programme.

As with Lamb and Aldous, Cajkler and Wood's article on mentors and student teachers "lesson studying" in initial teacher education, contributes to the growing adoption of Lesson Study in England's university and school initial teacher education partnerships. Presenting a dyadic version of Lesson Study between mentors and preservice teachers, Cajkler and Wood explored Lesson Study as a vehicle for supporting preservice teachers' learning during school placements. The findings present both preservice and mentor perspectives on the use of Lesson Study during teaching practice, highlighting the value for both sets of stakeholders in the process. Mentor-led Lesson Study supports the transition into teaching for those just starting out in the profession, developing what the authors refer to as pedagogic literacy, whilst challenging reductive approaches to initial teacher education.

Gierlinger et al., discuss the feasibilities and difficulties in establishing Learning Study, with the underpinning of Variation Theory, as integral within Austrian initial English as a Foreign Language teacher education, using a hermeneutic and epistemological approach. The paper addresses three key issues. First, it explores the question of how deeper understanding around the object of learning could be conceptualised and measured in EFL learning contexts. Second, it investigates the extent to which the core principles of Learning Study align with the pertinent concepts of second language acquisition. Third, it examines the potential contribution of Variation Theory to secondary and tertiary levels of education in Austria, and the roles of different stakeholders at each level. The conceptual paper reveals that there is great potential for Variation Theory and Learning Study to be adopted in EFL teaching and learning in Austria.

The case study conducted by Chichibu examines the impact of Lesson Study for initial teacher training in Japan, with a focus on mentor roles, and kyouzai-kenkyu. It explains how the professional advice given by independent mentors in the post-lesson conference help develop instructional and thinking skills of the initial teachers in Japan. Due to the time constraint of the post-lesson discussion and the differences in instructional contexts, it is quite challenging for mentors to identify the problem(s) of a lesson and give suggestions for improvement. The article discloses what Japanese teachers perceive lesson plans and how mentors develop the understanding of kyouzaikenkyu (curriculum study) among preservice teachers.

Soto Gómez et al. focus on learning to teach with Lesson Study through reflective and cooperative creation as a strategy for research and improvement of teaching practice, and students' learning. They report on a four-year preservice programme in a Spanish university, designed with lesson study as a core component, within two key areas of the syllabus - the practicum in school and the degree essay. The authors incorporated Lesson Study within the existing structures of their programme consisting of an autonomous intervention project (degree essay), blended within the third practicum teaching experience. The goal of their innovative design was to explore how Lesson Study may scaffold existing aims to train reflective and questioning teachers who know how to work both cooperatively and independently. This is the first opportunity for Lesson Study to be embedded within the author's university and provides an enthusiastic endorsement for other initial teacher educators to consider. 
Munthe $e t$ al. present a time-lagged experiment of Lesson Study in field practice in initial teacher education in Norway, attempting to shift preservice teachers' focus from themselves to their pupils, thus strengthening their learning about the consequences of their instructional decisions for their pupils. An interesting caveat to this article is its cross-disciplinary approach to implementing Lesson Study during school-based training and demonstrates both the potential and power of Lesson Study, whilst also echoing the challenges within the initial teacher education context. Whilst acknowledging much good existing initial teacher education practice, referred to as "the business as usual approach" the article demonstrates the usefulness of Lesson Study in scaffolding a shift from an individualised approach to learning as demonstrated through the business as usual model, to learning through collaborative inquiry.

\section{Concluding thoughts}

This special issue has sought to share approaches to Lesson and Learning Study being adopted and adapted by initial teacher educators around the world. Whilst the studies themselves are all small scale, the potential impact is huge. Today's preservice teachers are tomorrow's educational leaders. If Lesson and Learning Study is to be embraced and integrated within the daily routines of good educational practice, there's no better time to initiate collaborative practice and pedagogy, than when training to teach. As new entrants to the profession embark on their first teaching posts, the impact of their professional socialisation (Lawson, 1983) should not be underestimated. Sharing their Lesson and Learning Study experiences from their training with new colleagues can espouse a new generation of engagement in Lesson and Learning Study. However, as the different studies reported on here highlight, it is necessary for teacher educators to demonstrate innovation in their training practices whilst working with schools that are equally willing to be innovative and share the same goals (Curtner-Smith, 1999; Schempp and Graber, 1992). Most of the articles in this special issue highlight various challenges faced by preservice teachers and school mentors when engaging in models of Lesson and Learning Study, not least time constraints and the sheer logistics of fitting in full cycles of Lesson Study amidst the plethora of formalised structures and assessment processes associated with meeting required standards of performance (Chassels and Melville, 2009). Additionally, support from experienced teachers during school-based training may be a barrier due to the formal hierarchical relationship between the preservice teacher and established school mentor (Le Cornu, 2005; Lamb, 2015). Nevertheless, there is much anecdotal evidence here to endorse the adopting of Lesson and Study as an integral element of initial teacher training programmes.

As guest editors, we appreciate the hard work by all the authors in meeting the inherent time constraints involved in putting together a special issue. We believe such efforts have paid off in terms of the contribution this special issue makes to the dialogue and impact of Lesson and Learning Study in initial teacher education. The articles develop the literature in terms of the aspects of mentors' roles, the development of reflective practice and teaching competences; as well as the possibilities and challenges of adopting Variation Theory in preservice teacher training programmes. The novel and ingenious ways in which initial teacher educators have embraced Lesson and Learning Study, as presented in this special issue, provides valuable material for all initial teacher educators. It cannot be denied that one of the overarching aims for the initial teacher education community is to facilitate reflective new teachers, who autonomously and proactively look to engage in collaborative 
IJLLS

5,2

inquiry as their default position. It is hoped that the collection of articles presented in the special issue by those that endorse the positive benefits of Lesson and Learning Study, may galvanise other initial teacher educators into exploring such authentic opportunities for their cohorts during their school-based and field experiences.

\section{References}

Cajkler, W. and Wood, P. (2016), "Mentors and student-teachers 'lesson studying' in initial teacher education”, International Journal for Lesson \& Learning Studies, Vol. 5 No. 2, pp. 84-98.

Chassels, C. and Melville, W. (2009), "Collaborative, reflective, and iterative Japanese lesson study in an initial teacher education program: benefits and challenges", Canadian Journal of Education, Vol. 32 No. 4, pp. 734-763.

Chichibu, T. (2016), "Impact on lesson study for initial teacher training in Japan: focus on mentor roles and kyouzai-kenkyuu", International Journal for Lesson \& Learning Studies, Vol. 5 No. 2, pp. 155-168.

Cohan, A. and Honigsfeld, A. (2006), "Incorporating 'lesson study' in teacher preparation", The Educational Forum, Vol. 71 No. 1, pp. 81-92.

Curtner-Smith, M. (1999), "The more things change the more they stay the same: factors influencing teachers' interpretations and delivery of national curriculum physical education”, Sport, Education \& Society, Vol. 4 No. 1, pp. 75-97.

Davies, P. and Dunnill, R. (2008), "Learning study as a model of collaborative practice in initial teacher-education", Lournal of Education for Teaching, Vol. 34 No. 1, pp. 3-16.

Elliott, J. (2012), "Developing a science of teaching through lesson study", International Journal of Learning and Lesson Studv, Vol. 1 No. 2, pp. 108-125.

Fernandez, M.L. and Robinson, M. (2006), "Prospective teachers' perspectives on microteaching lesson study”, Education, Vol. 127 No. 2, pp. 203-215.

Gierlinger, E.M., Spann, H. and Wagner, T. (2016), "Variation theory in Austrian initial EFL teacher education: potentials and challenges", International Iournal for Lesson \& Learning Studies, Vol. 5 No. 2, pp. 130-141.

Gurl, T. (2011), “A model for incorporating lesson study into the student teaching placement: what worked and what did not?", Educational Studies, Vol. 37 No. 5, pp. 523-528.

Ko, P.Y. (2012), "Critical conditions for preservice teachers' learning through inquiry: the learning study approach in Hong Kong”, International Journal for Lesson and Learning Studies, Vol. 1 No. 1, pp. 49-64.

Lamb, P. (2015), "Peer-learning between preservice teachers: embracing lesson study", International Iournal for Lesson and Learning Studies, Vol. 4 No. 4, pp. 343-361, available at: http://dx.doi.org/10.1108/IJLLS-03-2015-0012 (accessed 5 February 2016).

Lamb, P. and Aldous, D. (2016), "Exploring the relationship between reflexivity and reflective practice through lesson study within initial teacher education", International Iournal for Lesson \& Learning Studies, Vol. 5 No. 2, pp. 99-115.

Lawson, H.A. (1983), "Toward a model of teacher socialization in physical education: the subjective warrant, recruitment, and teacher education (part 1)", Journal of Teaching in Physical Education, Vol. 2 No. 3, pp. 3-16.

Le Cornu, R. (2005), "Peer mentoring: engaging preservice teachers in mentoring one another", Mentoring and Tutoring, Vol. 13 No. 3, pp. 355-366.

Marble, S.T. (2006), "Learning to teach through lesson study", Action in Teacher Education, Vol. 28 No. 3, pp. 86-96. 
Marble, S.T. (2007), "Inquiring into teaching: lesson study in elementary science methods", Case studies of Journal of Science Teacher Education, Vol. 18 No. 6, pp. 935-953.

Munthe, E., Bjuland, R. and Helgevold, N. (2016), "Lesson study in field practice: a time-lagged experiment in initial teacher education in Norway", International Iournal for Lesson \& Learning Studies, Vol. 5 No. 2, pp. 142-154.

Parks, A.N. (2008), "Messy learning: preservice teachers' lesson-study conversations about mathematics and students", Teaching \& Teacher Education, Vol. 24 No. 5, pp. 1200-1216. , A.N. (2009), "Collaborating about what? An instructor's look at preservice lesson study", Teacher Education Quarterly, Vol. 36 No. 4, pp. 81-97.

Santagata, R., Zannoni, C. and Stigler, J.W. (2007), "The role of lesson analysis in preservice teacher education: an empirical investigation of teacher learning from a virtual video-based field experience", Journal of Mathematics Teacher Education, Vol. 10 No. 2, pp. 123-140.

Schempp, P.G. and Graber, K.C. (1992), "Teacher socialization from a dialectical perspective: pre-training through induction”, Journal of Teaching in Physical Education, Vol. 11 No. 4, pp. 29-348.

Schon, D.A. (1987), Educating the Reflective Practitioner: Toward a New Design For Teaching and Learning in the Professions, Jossey-Bass, San Francisco, CA.

Sims, L. and Walsh, D. (2009), "Lesson study with preservice teachers: lessons from lessons", Teaching and Teacher Education, Vol. 25 No. 5, pp. 724-733.

Soto Gómez, E., Serván Núñez, M.J. and Caparros-Vida, R. (2016), "Learning to teach with lesson study: the practicum and the degree essay as the scenario for reflective and cooperative creation", International Journal for Lesson \& Learning Studies, Vol. 5 No. 2, pp. 116-129.

Van Maanen, J. and Schein, E.H. (1979), "Toward a theory of organizational socialization", in Straw, B. (Ed.), Research in Organizational Behavior, Vol. 1, JAI Press, Greenwich, CT, pp. 209-261.

\section{About the authors}

Dr Penny Lamb is a Senior Lecturer in Education in the School of Education and Lifelong Learning, University of East Anglia, UK. Dr Penny Lamb is the corresponding author and can be contacted at: penny.lamb@uea.ac.uk

Dr Po Yuk Ko is an Associate Professor in the Department of Curriculum and Instruction and the Director of the Centre for Excellence in Learning and Teaching (CELT) at the Hong Kong Institution of Education, Hong Kong.

For instructions on how to order reprints of this article, please visit our website:

www.emeraldgrouppublishing.com/licensing/reprints.htm

Or contact us for further details: permissions@emeraldinsight.com 